\title{
PENERAPAN MODEL PEMBELAJARAN KOOPERATIF TIPE TEAM GAMES TOURNAMENT (TGT) MELALUI MEDIA POWERPOINT GUNA MENINGKATKAN HASIL BELAJAR SEJARAH PESERTA DIDIK
}

\author{
Nurul Fauziyah \\ Program Studi Pendidikan Sejarah FKIP Universitas Lambung Mangkurat \\ Banjarmasin \\ Email: 1710111220023@mhs.ulm.ac.id
}

\begin{abstract}
Abstrak: Pendidikan dalam pengertian paling sederhana merupakan proses transfer budaya, yang didalamnya juga meliputi sistem pengetahuan, bahasa, religi, mata pencaharian dan lain sebagainya (Syaharuddin \& Susanto, Heri, 2019: 12). Sehingga pendidikan mempunyai peranan yang sangat penting dan kompleks demi kemajuan suatu bangsa. Penggunaan model pembelajan untuk menunjang kegiatan belajar mengajar sangatlah dibutuhkan bagi guru maupun peserta didik. Dimana suatu model pembelajaran dapat membuat pesera didik aktif, kreatif, inovatif dan menyenangkan sehingga materi yang diajarkan dapat melekat dalam ingatan peserta didik dan memberikan dampak pada hasil belajar yang dicapai. Model Team Games Tournament (TGT) melalui media powerpoint ini diharapkan dapat meningkatkan keterampilan guru, aktivitas dalam kegiatan belajar mengajar dan hasil belajar sejarah peserta didik. Penerapan model pembelajaran TGT (Team Games Tournament) sebagai salah satu alternatif model pembelajaran inovatif untuk meningkatkan kualitas pembelajaran sejarah.
\end{abstract}

Kata kunci: Model Pembelajaran TGT, Media Powerpoint, Hasil Belajar Sejarah

\section{PENDAHULUAN}

Menurut Undang-undang Nomor 20 Tahun 2003 tentang sistem pendidikan nasional, mendefinisikan pendidikan sebagai “.....usaha sadar mewujudkan suasana belajar dan proses pembelajaran agar peserta didik belajar secara aktif mengembangkan potensi dirinya untuk memiliki kekuatan spiritual keagamaan, kepribadian, kecerdasan, akhlak mulia, serta keterampilan yang diperlukan dirinya, masyarakat, bangsa, dan Negara." Berdasarkan definisi ini sehingga muncul suatu paradigm yang baru dalam dunia pendidikan agar lebih menekankan pada proses pembelajaran yang komprehensif dan berkualitas (Suyanto \& Jihad, A., 2013: 251). Oleh sebab itu, maka pendidikan adalah suatu aktivitas atau usaha manusia untuk meningkatkan kepribadiannya, baik itu berupa tingkah laku maupun kecerdasannya dengan tujuan untuk membina potensi-potensi yang ada pada diri setiap peserta didik.

Pendidikan mempunyai peranan yang penting bagi kemajuan dan masa depan bangsa. Pelaksanaan pendidikan bertujuan untuk mengembangkan individu peserta didik, dalam arti memberikan kesempatan kepada mereka untuk mengembangkan potensi mereka secara alami dan apa adanya (Rusman, dkk., 2011: 41). Penggunaan model pembelajaran diharapkan dapat meningkatkan hasil belajar sejarah peserta didik agar bisa aktif, kreatif, dan produktif. Maka harus dilakukan suatu hal yang menarik, yaitu melalui kegiatan pembelajaran, dimana untuk kegiatannya perlu disiapkan guru yang profesional yang mampu merencanakan, melaksanakan, melakukan monitoring dan evaluasi, serta memberikan jaminan mutu dan mempertanggungjawabkan suatu pembelajaran (Mulyasa, 2014: 1-2). 
Suprijono (2016: 30) menyatakan bahwa pembelajaran adalah proses organik dan konstruktif berupa dialog interaktif dan berpusat pada peserta didik. Kegiatan belajar itu sendiri merupakan suatu proses perubahan tingkah laku sebagai hasil dari interaksi dengan lingkungannya dalam memenuhi kebutuhan hidupnya (Slameto, 2015: 1-2). Dalam proses pembelajaran perlu digunakan suatu model pembelajaran yang dapat membuat pesera didik aktif, kreatif, inovatif dan menyenangkan agar materi yang diajarkan dapat melekat dalam ingatan peserta didik dan memberikan dampak pada hasil belajar yang dicapai. Salah satu model yang dapat digunakan adalah model Team Games Tournament (TGT) melalui media powerpoint. Dimana peserta didik mengkonstruksi sendiri pengetahuannya dan pemahamannya melalui game dalam bentuk kuis yang disajikan di powepoint.

\section{TEORI BELAJAR YANG MENDASARI MODEL PEMBELAJARAN KOOPERATIF TIPE TGT MELALUI MEDIA POWERPOINT}

Menurut Prastowo (2013: 73) bahwa model pembelajaran adalah acuan pembelajaran yang dilaksanakan berdasarkan pola-pola pembelajaran tertentu secara sistematis. Ciri khas model pembelajaran adalah berdasarkan teori pendidikan dan teori belajar dari para ahli tertentu, mempunyai misi dan tujuan pendidikan tertentu, dapat dijadikan pedoman untuk perbaikan proses belajar mengajar dikelas, memiliki bagian-bagian model yang dinamakan urutan langkah-langkah pembelajaran (syntax), adanya prinsip-prinsip reaksi, sistem sosial dan sistem pendukung, memiliki dampak sebagai akibat penerapan model pembelajaran dan membuat persiapan mengajar (desain instruksional) dengan pedoman model pembelajaran yang dipilihnya. Teori belajar yang mendasari pembelajaran Sejarah dengan model TGT (Team Game Tournament ) melalui media Powerpoint adalah:

1. Teori Belajar Kontruktivisme

Belajar adalah lebih dari sekedar mengingat. Peserta didik yang memahami dan mampu menerapkan pengetahuan yang telah dipelajari, mereka harus mampu memecahkan masalah, menemukan (discovery) sesuatu untuk dirinya sendiri, dan berkutat dengan berbagai gagasan. Inti sari kontruktivisme adalah bahwa peserta didik harus menemukan dan mentransformasikan informasi kompleks ke dalam dirinya sendiri (Rifa'i, Ahmad \& Anni, Catharina Tri, 2011: 137). Pendekatan konstruktivis dalam pembelajaran sejarah dapat diarahkan pada proses pencarian fakta dan proses menyusun kembali/rekonstruksi peristiwa sejarah. Dengan kegiatan tersebut diharapkan peserta didik mampu menemukan dan membuat konstruksi ide dari suatu peristiwa (Susanto, 2015: 29) Semua pengetahuan adalah hasil konstruksi dari kegiatan atau tindakan seseorang. Pengetahuan ilmiah berevolusi, berubah dari waktu ke waktu. pemikiran ilmiah adalah sementara, tidak statis, dan merupakan proses (Suprijono, 2016).

Strategi pengajaran dengan prinsip konstruktivisme menghendaki guru untuk mampu merancang sebuah desain pembelajaran yang memungkinkan peserta didik untuk mendapatkan, menyusun, dan membangun pengetahuannya sendiri dibawah bimbingan guru. Secara holistic strategi dimulai dari perencanaan pengajaran (pra instruksional), proses pembelajaran (instruksional) dan evaluasi pembelajaran (Susanto, 2014: 94). Jadi, model pembelajaran TGT (Team Games Tournament) didasarkan pada teori belajar kontruktivis, dimana peserta didik mengkontruksi sendiri pengetahuannya dan pemahamannya melalui game yang disajikan. 


\section{Teori Belajar Kognitif}

Menurut Suprijono (2016) dalam persepsi teori kognitif, belajar merupakan peristiwa mental, bukan peristiwa behaviorial meskipun hal-hal yang bersifat behaviorial tampak lebih nyata hampir dalam setiap peristiwa belajar. Belajar adalah proses aktif mental untuk mencapai, mengingat, dan menggunakan pengetahuan. Belajar adalah perubahan persepsi dan pemahaman (tidak selalu berbentuk perubahan tingkah laku yang dapat diamati). setiap orang mempunyai pengetahuan/pengalaman dalam dirinya, yang tertata dalam bentuk struktur kognitif (Sani, 2013: 10). Jadi, model pembelajaran TGT (Team Games Tournament) untuk hasil belajar peserta didik digali melalui proses daya ingat dan pemikiran sehingga sesuai dengan teori belajar kognitif.

3. Teori Belajar Brunner

Teori belajar Bruner menyatakan bahwa yang terpenting dalam belajar adalah cara-cara bagaimana seseorang memilih, mempertahankan, dan mentransformasikan informasi yang diterimanya secara aktif. Menurut Bruner, pada dasarnya belajar merupakan proses kognitif yang terjadi dalam diri seseorang. Ada tiga proses kognitif yang terjadi dalam belajar, yaitu (1) proses perolehan informasi baru; (2) proses mentransformasikan informasi yang diterima; dan (3) menguji relevansi dan ketepatan pengetahuan (Winaputra, 2008: 313).

Jika dihubungkan dengan teori bruner, dalam pelaksanaannya model pembelajaran TGT (Team Games Tournament) menghadirkan peserta didik memperoleh informasi dan mentransformasikan informasinya lewat permainan yang menarik bagi peserta didik.

\section{IMPLEMENTASI MODEL PEMBELAJARAN KOOPERATIF TIPE TEAM GAMES TOURNAMENT (TGT) MELALUI MEDIA POWERPOINT}

Model pembelajaran TGT (Team Games Tournament) adalah salah satu model pembelajaran kooperatif yang mudah diterapkan melibatkan aktivitas seluruh siswa tanpa adanya perbedaan status, melibatkan peran siswa sebagai tutor sebaya, dan mengandung unsur permainan dan reinforcement. Aktivitas siswa dengan model TGT memungkinkan siswa dapat belajar lebih rileks disampung menumbuhkan tanggung jawab, kerja sama, persaingan sehat dan keterlibatan belajar (Hamdani, 2011: 92)

Model pembelajaran kooperatif tipe Teams Games Tournaments (TGT) yang pada mulanya dikembangkan oleh David De Vries dan Keith Edwards ini merupakan metode pembelajaran pertama dari Johns Hopkins (Huda, 2015: 117). Model pembelajaran kooperatif tipe TGT ini menambahkan dimensi kegembiraan yang diperoleh dari penggunaan permainan. Mulyatiningsih (2014: 244) menyatakan bahwa TGT melibatkan aktivitas seluruh siswa tanpa harus ada perbedaan status, melibatkan siswa sebagai tutor teman sebaya dan mengandung unsur permainan dan penguatan.

Rusman (2012: 224) menjelaskan bahawa TGT adalah salah satu tipe pembelajaran kooperatif yang menempatkan siswa dalam kelompok-kelompok belajar yang beranggotakan 5-6 siswa yang memiliki kemampuan, jenis kelamin, dan suku atau ras yang berbeda. TGT Menggunakan turnamen akademik, dan menggunakan kuis-kuis dan sistem skor kemajuan individu, dimana peran siswa berlomba sebagai wakil tim mereka dengan anggota tim lain yang kinerja akademik sebelumnya setara seperti mereka. (Slavin, 2005: 163) 
Jadi, pedoman yang dapat dilakukan guru dalam kegiatan pembelajaran untuk meningkatkan keefektifan kegiatan belajar mengajar agar bisa terpenuhi dengan baik. Maka model pembelajaran TGT merupakan salah satu model pembelajran kooperatif dimana bagiannya terdiri dari penyampaian materi secara klasikal, pengelompokan, permainan, turnamen, dan penghargaan kelompok. Model TGT (Team Games Tournament) akan dapat menambah motivasi, rasa percaya diri, toleransi, kerjasama dan pemahaman materi siswa.

Menurut Slavin (Taniredja, 2012: 67) menyatakan ada lima komponen utama dalam model pembelajaran kooperatif tipe TGT (Team Games Tournament), antara lain:

1. Penyajian Kelas (Class Pressentation)

Penyajian kelas dalam pembelajaran kooperatif tipe Teams Games Tournaments (TGT) tidak berbeda dengan pengajaran klasikal oleh guru, hanya pengajaran lebih difokuskan pada materi yang sedang dibahas saja. Ketika penyajian kelas berlangsung, mereka sudah berada dalam kelompoknya. Dengan demikian mereka akan memperhatikan dengan serius selama pengajaran penyajian kelas berlangsung sebab setelah ini mereka harus mengerjakan games akademik dengan sebaik-baiknya dengan skor mereka akan menentukan skor kelompok mereka.

2. Kelompok (Teams)

Kelompok disusun beranggotakan 4-5 orang yang mewakili pencampuran dari berbagai keragaman dalam kelas seperti kemampuan akademik, jenis kelamin, rasa, atau etnik. Fungsi utama mereka dikelompokkan adalah anggota-anggota kelompok saling meyakinkan bahwa mereka dapat bekerja sama dengan baik dalam belajar dan mengerjakan game atau lembar kerja dan lebih khusus lagi untuk menyiapkan semua anggota dalam menghadapi kompetisi.

3. Permainan (Games)

Pertanyaan dalam game disusun dan dirancang dari materi yang relevan denan materi yang telah disajikan untuk menguji pengetahuan yang diperoleh mewakili masing-masing kelompok. Sebagian besar pertanyaan pada kuis adalah bentuk sederhana. Setiap peserta didik mengambil sebuah kartu yang diberi nomor dan menjawab pertanyaan yang sesuai dengan nomor pada kartu tersebut.

4. Kompetisi/ Turnamen (Tournaments)

Turnamen adalah susunan beberapa game yang dipertandingkan. Game ini dilaksanakan pada akhir minggu atau akhir unit pokok bahasan, setelah guru memberikan penyajian kelas dan kelompok mengerjakan lembar kerjanya.

5. Pengakuan Kelompok (Teams Recognition)

Pengakuan kelompok dilakukan dengan memberikan penghargaan berupa hadiah, sertifikat, atau medali penghargaan atas usaha yang telah dilakukan kelompok selama belajar sehingga mencapai kriteria yang telah disepakati bersama.

Tabel 1: Penghargaan Tim

\begin{tabular}{|c|c|}
\hline Kriteria (rata-rata tim) & Penghargaan \\
\hline 40 & Tim Baik \\
\hline 45 & Tim Sangat Baik \\
\hline 50 & Tim Super \\
\hline
\end{tabular}


Menurut (Taniredja, 2012: 72-73) kelebihan model pembelajaran kooperatif tipe TGT (Team Games Tournament) adalah dalam kelas kooperatif siswa memiliki kebebasan untuk berinteraksi dan menggunakan pendapatnya, rasa percaya diri siswa menjadi tinggi, perilaku mengganggu terhadap siswa lain menjadi lebih kecil, motivasi belajar siswa bertambah, pemahaman yang lebih mendalam terhadap materi pelajaran, meningkatkan kebaikan budi, kepekaan, toleransi antara siswa dengan siswa dan antara siswa dengan guru, kerjasama antar siswa akan membuat interaksi belajar dalam kelas menjadi hidup dan tidak membosankan. Sedangkan, kelemahan model pembelajaran kooperatif tipe TGT (Team Games Tournament) adalah sering terjadi dalam kegiatan pembelajaran tidak semua siswa ikut serta menyumbangkan pendapatnya, kekurangan waktu untuk proses pembelajaran dan memungkinan terjadinya kegaduhan kalau guru tidak dapat mengelola kelas.

Langkah-langkah Model Pembelajaran Kooperatif Tipe TGT berdasarkan pendapat Taniredja (2012), berdasarkan urutan sebagai berikut: pengaturan klasikal, belajar kelompok, turnamen akademik, dan penghargaan tim.

a. Pengaturan Klasikal

Pembelajaran diawali dengan memberikan pelajaran, selanjutnya diumumkan kepada semua peserta didik bahwa akan melaksanakan pembelajaran kooperatif tipe Teams Games Tournaments (TGT) dan peserta didik diminta memindahkan bangku untuk membentuk meja tim.

b. Belajar Kelompok

Peserta didik diberi informasi bahwa mereka akan bekerja sama dengan kelompok belajar selama beberapa pertemuan, mengikuti turnamen akademik untuk memperoleh poin untuk skor tim mereka serta diberitahukan tim yang mendapat nilai tinggi akan mendapat penghargaan.

c. Turnamen Akademik

Kegiatan dalam turnamen adalah persaingan pada meja turnamen dari 3-4 peserta didik dari tim yang berbeda dengan kemampuan setara. Pada permulaan turnamen diumumkan penetapan meja bagi peserta didik. Peserta didik diminta mengatur meja turnamen yang ditetapkan. Nomor meja turnamen bisa diacak. Setelah kelengkapan dibagikan dapat dimulai kegiatan turnamen.

d. Penghargaan Tim

Pada akhir putaran pemenang mendapat satu kartu bernomor, penantang yang kalah mengembalikan perolehan kartunya bila sudah ada namun jika pembaca kalah tidak diberikan hukuman. Penyekoran didasarkan pada jumlah perolehan kartu, misalkan pada meja turnamen terdiri dari 3 peserta didik yang tidak seri, peraih nilai tertinggi mendapat skor 60, kedua 40, dan ketiga 20. Masing-masing perwakilan kelompok kembali ke kelompok masing-masing untuk menghitung skor yang diperoleh. Kelompok yang memiliki skor terbanyak diberikan penghargaan berupa medali dan diumumkan sebagai kelompok super, sangat baik, dan baik.

Media pembelajaran dapat dipahami sebagai segala sesuatu yang dapat menyampaikan atau menyalurkan pesan dari suatu sumber secara terencana dan tepat guna, sehingga tercipta lingkungan yang kondusif dimana penerimanya dapat melakukan kegiatan belajar secara efektif dan efesien (Susanto, Heri \& Akmal, Helmi, 2019: 16). Pada media powerpoint dalam model pembelajaran kooperatif tipe TGT ini adalah dalam bentuk kuis. 
Powerpoint merupakan salah satu aplikasi yang paling banyak digunakan oleh orangorang dalam mempresentasikan bahan ajar atau laporan, karya atau status mereka (Arsyad, 2013: 193). Dengan Powerpoint kita dapat merancang dan membuat presentasi yang lebih menarik dan professional. Pemanfaatan media presentasi ini dapat dimanfaatkan oleh pendidik maupun peserta didik untuk mempresentasikan materi pelajaran maupun tugas-tugas yang akan diberikan. Jadi, media Powerpoint adalah salah satu produk dari Microsoft Corporation yang dapat digunakan sebagai media presentasi maupun media pembelajaran yang dapat memaparkan materi dengan tampilan yang menarik yang dapat memotivasi siswa peserta didik untuk dapat tertarik dalam materi yang disampaikan.

Langkah-langkah penggunaan media powerpoint menurut (Indriana, 2011: 154), adalah sebagai berikut:

a. Membentuk kelompok dalam kelas.

b. Menyusun topik.

c. Menulis naskah lengkap.

d. Menyusun point of talks, yakni hal-hal yang akan disampaikan.

e. Memasukkan data kedalam computer dengan bantuan program MS Powerpoint.

f. Mempresentasikan menggunakan sejumlah alat bantu.

g. Tanya jawab/diskusi.

h. Evaluasi.

Berdasarkan langkah-langkah yang telah dijelaskan, baik untuk model pembelajaran TGT maupun dalam penggunaan media powerpoint. Jika digabungkan akan menghasilkan langkah-langkah pembelajaran TGT melalui media powerpoint dalam pembelajaran sejarah, sebagai berikut:

a. Menjelaskan materi menghargai jasa dan peranan tokoh dalam mem-proklamasikan kemerdekaan yang diajarkan dengan menggunakan Powerpoint sebagai media.

b. Membagi siswa menjadi beberapa kelompok secara heterogen yang terdiri dari 4-5 anak.

c. Menempatkan siswa dari tim yang berbeda dengan kemampuan homogen atau setara untuk memainkan game atau permainan akademik tentang menghargai jasa dan peranan tokoh dalam memproklamasikan kemerdekaan.

d. Memberikan penghargaan kepada kelompok yang mendapatkan rata-rata tim 40 mendapat predikat Tim Baik, skor 45 mendapat predikat Tim Sangat Baik, dan skor 50 mendapat predikat Tim Super.

e. Melakukan evaluasi pembelajaran secara individu dalam materi menghargai jasa dan peranan tokoh dalam memproklamasikan kemerdekaan

Jadi, dalam model pembelajaran kooperatif tipe TGT ini menggunakan 4 tahap yaitu tahap presentasi kelas (tahap mengajar), tahap belajar dalam kelompok, tahap kompetisi atau turnamen, dan tahap penghargaan tim. Guru dapat memilih model pembelajaran kooperatif tipe TGT ini karena faktor menyenangkan dan dapat meningkatkan hasil belajar. Sehingga peserta didik tidak bosan pada saat kegiatan pembelajaran berlangsung. Dalam model pembelajaran ini pengelompokan siswa berdasarkan prinsip heterogenitas baik dari segi kemampuan akademik, jenis kelamin, maupun ras. Variasi metode yang dilakukan ini dapat membuat siswa tertarik dengan mata pelajaran sejarah. Hasil penelitian ini diharapkan dapat menjadi salah satu upaya untuk meningkatkan pengajaran di sekolah terutama pada mata pelajaran sejarah sehingga hasil belajar peserta didik menjadi lebih baik. 


\section{HASIL BELAJAR SEJARAH PESERTA DIDIK}

Keberhasilan pengajaran dapat dilihat dari segi hasil. Proses pengajaran yang optimal memungkinkan hasil belajar sejarah yang optimal juga. Ada korelasi antara proses pengajaran dengan hasil belajar. Semakin besar usaha untuk menciptakan kondisi proses pengajaran, semakin tinggi pula hasil dari pengajaran tersebut (Sudjana, 1989: 37). Menurut Heri Susanto (2017: 44) menyatakan bahwa pendidikan merupakan proses internalisasi nilai termasuk nilai nasionalisme, maka pemahaman merupakan salah satu aspek penting dari proses internalisasi nilai nasionalisme tersebut. Pemahaman sejarah dalam hal ini sejarah perjuangan bangsa merupakan proses penanaman nasionalisme melaui penyadaran terhadap realita sejarah yang membentuk identitas kebangsaan (Susanto, 2013: 96).

Made Wena (2011: 6) mengemukakan bahwa pengertian hasil belajar adalah polapola perbuatan, nilai-nilai, pengertian-pengertian, sikap-sikap, apresiasi dan keterampilan. Hasil belajar menurut Degeng adalah semua efek yang dapat dijadikan sebagai indikator tentang nilai dari penggunaan strategi pembelajaran dibawah kondisi yang berbeda. Hasil belajar merupakan perubahan perilaku yang diperoleh peserta didik setelah mengalami kegiatan belajar (Rifa'i dan Anni, 2011: 85). Hasil belajar merupakan kemampuan yang diperoleh peserta didik setelah melakukan proses belajar. Peserta didik dikatakan berhasil dalam belajar apabila mampu mencapai tujuan-tujuan dari belajar tersebut.

Hasil belajar dapat diperoleh dari proses evalasi hasil belajar siswa. Rendahnya hasil belajar yang diperoleh siswa tidak semata-mata disebabkan oleh kemampuan peserta didik tersebut dalam belajar melainkan juga disebabkan kurang berhasilnya guru dalam mengajar. Sehingga ada keterkaitan keberhasilan antara guru dengan peserta didik. Berdasarkan pendapat diatas dapat disimpulkan bahwa hasil belajar sejarah adalah hasil yang diperoleh peserta didik setelah mendapat pengetahuan selama proses belajar mengajar. Hasil belajar sejarah dapat diwujudkan berupa nilai maupun dari pengukuran (evaluasi) peserta didik.

\section{PENUTUP}

Pembelajaran merupakan proses interaksi antara guru dengan peserta didik. Sehingga mampu mendapatkan pengalaman belajar yang baik dan berkualitas dari kegiatan tersebut. Dalam proses pembelajaran pemilihan suatu metode sangat menentukan kualitas pembelajaran. Pada masa kini seiring dengan proses peningkatan kualitas pembelajaran, maka dalam kurikulum 2013 dianjurkan adanya variasi metode yang dapat melibatkan siswa secara aktif dalam proses belajar mengajar. Variasi metode dapat ditunjukkan ketika guru mampu menerapkan suatu model pembelajaran dalam menyampaikan materi pada peserta didik. Salah satu pembelajaran yang mampu melibatkan siswa aktif adalah pembelajaran yang bersifat konstruktivis. Dalam pembelajaran yang bersifat konstruktivis ini ada beberapa model yang dapat diterapkan, salah satunya adalah model pembelajaran kooperatif tipe TGT (Team Games Tournament).

Pembelajaran kooperatif tipe TGT (Team Games Tournament) ini adalah suatu model pembelajaran yang didalamnya terdapat unsur permainan. Dalam hal ini peneliti peneliti menggunakan media powerpoint sebagai penunjang dalam penerapan model pembelajaran TGT ini. Penelitian ini diharapkan dapat menjadi bahan masukan bagi para guru dan dapat meningkatkan kompetensinya dalam pembelajaran sejarah. Selain itu juga agar dapat meningkatkan hasil belajar sejarah siswa. 


\section{DAFTAR PUSTAKA}

Arsyad, A. (2013). Media Pembelajaran. Jakarta: Raja Grafindo Persada.

Hamdani. (2011). Strategi Belajar Mengajar. Bandung: Pustaka Setia.

Huda, M. (2015). Cooperative Learning. Yogyakarta: Pustaka Pelajar.

Indriana, D. (2011). Ragam Alat Bantu Media Pengajaran. Yogyakarta: DIVA Press.

Mulyasa, E. (2014). Guru dan Implementasi Kurikulum 2013. Bandung: Remaja Rosdakarya.

Mulyatiningsih, E. (2014). Metode Penelitian Terapan Bidang Pendidikan. Yogyakarta: Alfabeta.

Prastowo, A. (2013). Pengembangan Bahan Ajar Tematik. Yogyakarta: DIVA Press.

Rifa'i, Ahmad \& Anni, Catharina Tri. (2011). Psikologi Pendidikan. Semarang: Universitas Negeri Semarang Press.

Rusman, dkk. (2011). Pembelajaran Berbasis Teknologi Informasi dan Komunikasi. Jakarta: Rajawali.

Sani, R. A. (2013). Inovasi Pembelajaran. Jakarta: Bumi Aksara.

Slameto. (2015). Belajar dan Faktor-faktor yang Mempengaruhinya. Jakarta: Rineka Cipta.

Slavin, R. (2005). Cooperative Learning. Bandung: Nusa Media.

Sudjana, N. (1989). Dasar-dasar Proses Belajar Mengajar. Bandung : Sinar Baru Algensindo.

Suprijono, A. (2016). Cooperative Learning. Yogyakarta: Pustaka Pelajar.

Susanto, Heri \& Akmal, Helmi. (2019). Media Pembelajaran Sejarah Era Teknologi Informasi. Banjarmasin: PSP Sejarah FKIP Universitas Lambung Mangkurat.

Susanto, H. (2013). Understanding of Regional History and Perception of Cultural Diversity in Developing Nasionalism. Historia:Jurnal Pendidik dan Peneliti Sejarah, Volume 14 (1), pp. 91-100.

Susanto, H. (2014). Seputar Pembelajaran Sejarah; Isu, Gagasan dan Strategi Pembelajaran. Yogyakarta: Aswaja Pressindo.

Susanto, H. (2015). Menghadirkan Kelas Konstruktivis dalam Melatih Kemampuan Berpikir Historis Melalui Kelas Model Latihan Penelitian. Pendidikan Sejarah untuk Menyiapkan Generasi Emas Indonesia 2050, 1 Desember, p. 29.

Susanto, H. (2017). Pemahaman Sejarah Daerah dan Persepsi Terhadap Keberagaman Budaya dalam membina sikap Nasionalisme (Studi Korelasi pada Mahasiswa Pendidikan Sejarah FKIP UNLAM). Sejarah dan Budaya: Jurnal Sejarah, Budaya, dan Pengajarannya, Volume 9 (1), pp. 39-50.

Suyanto \& Jihad, Asep. (2013). Menjadi Guru Profesional. Jakarta: Erlangga.

Syaharuddin \& Susanto, Heri. (2019). Sejarah Pendidikan Indonesia (Era Pra Kolonial sampai Reformasi). Banjarmasin: PSP Sejarah FKIP Universitas Lambung Mangkurat.

Taniredja, T. (2012). Model-model Pembelajaran Inovatif. Bandung: Alfabeta.

Wena, M. (2011). Strategi Pembelajaran Inovatif Kontemporer Suatu Tinjauan Konseptual Operasional. Jakarta: Bumi Aksara.

Winaputra, U. S. (2008). Teori Belajar dan Pembelajaran. Jakarta: Universitas Terbuka. 